\title{
GUIDANCE AND COUNSELING PROGRAMS FOR INCLUSIVE EDUCATION IN PRIMARY SCHOOL
}

\author{
Amalia Rizki Pautina, Wiwik Pratiwi, Sri Yunita Taligansing \\ Institut Agama Islam Negeri Sultan Amai Gorontalo

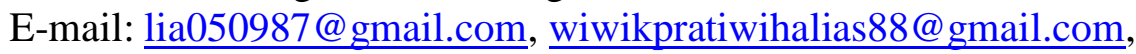 \\ taligansing.ugm@gmail.com
}

\begin{abstract}
Inclusive education is a form of education service which does not distinguish between regular students and those with special needs, whether physical, social, intellectual, emotional, linguistic and so on. It also includes students in remote or backward areas, isolated indigenous communities, and experiencing natural disasters, social disasters, and economically incapable of having education in regular schools from primary school till senior high school. In primary schools providing inclusive education, schools are required to make adjustments both in terms of curriculum, educational facilities, and infrastructure, as well as learning systems so that it suits the individual needs of students. Besides, to maximize the implementation of inclusive education in primary schools, guidance, and counseling programs oriented to each individual are needed. This study uses a qualitative approach to the literature review method. The result of this research is guidance and counseling program at inclusive schools is directed at developing personality and life skills so that students can participate in the community and not become a burden on the family or community. The implementation of guidance and counseling programs in primary schools implementing inclusive education is carried out in four stages: planning, designing, implementing and evaluating.
\end{abstract}

\section{Keywords: Guidance and Counseling, Inclusive Education, Primary Schools}

\section{INTRODUCTION}

Primary schools are an essential part of the National Education System in Indonesia. Primary schools are a low-level formal education which organizes education for six years. Law Number 20 the Year 2003 concerning the National Education System explains that primary schools include Sekolah Dasar/Madrasah Ibtidaiyah, Sekolah Menengah Pertama/Madrasah Tsanawiyah, or other forms of equivalent, while secondary education includes Sekolah Menengah Atas /Madrasah Aliyah Sekolah Menengan Kejuruan/Madrasah Aliyah Kejuruan or other forms of equivalent. ${ }^{1}$

Education is vital for everyone. Through education, a person can know and make a better attitude. Every Indonesian has the same opportunity of having an

\footnotetext{
${ }^{1}$ President of Republic of Indonesia, "the National Education System", Law of the Republic of Indonesia Number 20 of 2003, Pemerintah Republik Indonesia, 2003.

Volume XI, Number 2, December 2019; ISSN (Print): 2085-0034; ISSN (Online): 2549-3388 
education. Education is not only for a particular group such as the rich and physically perfect; the poor, even those with special needs, are entitled to an education. Children with special needs are children with unique and distinctive characteristics, and different from healthy children in general also need special education services.

The National Coordinating and Family Planning Board (BKKBN), estimates the number of school children is 42,870,041 people, and 10 percent of school-age children (5-14 years) have special needs ${ }^{2}$. Meanwhile, the number of $\mathrm{ABK}$ nationally in Indonesia that received education services is $30 \%(106,000$ children $)$ in 2012. In Yogyakarta, to date, as many as 189 ABK have received educational services from 332 total number of $\mathrm{ABK} .^{3}$

The Ministry of Education and Culture estimates that almost $70 \%$ of children with special needs did not get a proper education. The latest data from the Central Statistics Agency in 2017 stated that the number of children with special needs in Indonesia is as many as 1.6 million people. This statistic data means that there are more than one million children with special needs who have not yet acquired an essential education for their lives. Of the $30 \%$ of children with special needs who have obtained an education, only $18 \%$ of them got inclusive education, both from a particular school, and regular schools implementing inclusive education ${ }^{4}$.

The term "disabled" which was first conceived by Mansyur Fakih and Setya Adi Purwanta (a blind person) is not necessarily a substitute for the term disabled ${ }^{5}$. Historically, inclusive education has long been introduced in the world of education. This history refers to the results of the world conference on Education for All, which was held in 1990 in Thailand. The results of the conference included: bringing all children to school and provide all children with an appropriate education. ${ }^{6}$ Inclusive

2 AD, Yahya, and Siti Kristika. "Pengalaman Guru Bimbingan dan Konseling dalam Menangani Anak Berkebutuhan Khusus", Konseli: Jurnal Bimbingan dan Konseling 02, no. 2 (2015): 43-49.

3 Astri Hanjarwati and Siti Aminah, "Evaluasi Implementasi Kebijakan Pemerintah Kota Yogyakarta Mengenai Pendidikan Inklusi," Inklusi 1, no. 2 (2014): 221, https://doi.org/10.14421/ijds.010206.

4 Tika Anggreni Purba, "70 Persen Anak Berkebutuhan Khusus Tak Dapat Pendidikan Layak", https://lifestyle.bisnis.com/read/20190326/236/904431/70-persen-anak-berkebutuhan-khusus-tak-dapatpendidikan-layak, pada tanggal 29 Agustus 2019 pukul 14.20.

${ }^{5}$ M. Joni Yulianto, "Konsepsi Disabilitas Dan Pendidikan Inklusif," Inklusi 1, no. 1 (2014): 19, https://doi.org/10.14421/ijds.010102.

6 Badiah, Lutfi Isni, "Urgensi Bimbingan Dan Konseling Bagi Anak Berkebutuhan Khusus (ABK) di Sekolah Inklusi," Prosiding Seminar Nasional Peran Bimbingan dan Konseling dalam Penguatan Pendidikan Karakter Universitas Ahmad Dahlan, 2017, 123. 


\section{Amalia Rizki Pautina, Wiwik Pratiwi, Sri Yunita Taligansing}

education is an education service system that regulates children with special needs. They can be served in regular schools that are close to where they live with peers without having their specific class. Inclusion education schools start from $T K / R A, S D$ / MI, SMP / MTs, till SMA / SMK / MA levels.

In inclusive schools, the abilities of every child are heterogeneous. Besides normal children, there are also children with special needs who have a variety of disorders from intellectual, physical, social, emotional, and neurological sensors. To provide the best service for inclusive education in schools, in addition to modifying the learning model, guidance and counseling services also needed that are oriented to each individual.

Based on the previous explanation, the purpose of this article is to explain counseling guidance service programs that are arranged according to the needs of children with special needs to help students have a better accepting of themselves, know themselves, recognize their weaknesses, recognize their strengths so they can direct themselves according to their abilities so that they can develop optimally.

\section{RESEARCH METHOD}

This research is a literature review that describes counseling guidance service programs that can make children with special needs can develop optimally. The qualitative approach was an approach to explain that problem in this research deeply. This study also used primary and trusted reference sources from credible scientific journals and major reference books. The credential reference is that this study uses one of them is an accredited scientific journal. The focus of the research analysis in the discussion of the literature review is about the guidance and counseling service program in primary schools.

\section{RESULT AND DISCUSSION}

\section{Primary Schools and Its Characteristics}

Primary school is the most basic level of formal education in Indonesia, which is taken within six years, and this institution is neatly managed, and every activity is 
planned deliberately ${ }^{7}$. Primary schools are basic educational institutions that carry out six-year educational programs for children aged 6 to 12 years ${ }^{8}$. Elementary Schools as an early-stage formal educational institution for students that have the task of providing appropriate early-stage teaching and by the level of student abilities. ${ }^{9}$ Thus, it can be concluded that primary school is a formal educational institution at the level of primary education for children aged 7 to 12 years and organize for six years.

The primary school aims at preparing students ready to continue at the next level, namely junior high school or equivalent. Primary schools also facilitate students to interact and communicate more broadly even with new people, so that primary school education has the following objectives: first, guiding physical and spiritual growth and development, students' talents, and interests; second, provide essential knowledge, skills, and attitudes that are beneficial to students; third, establish a good society; fourth, continuing education at the junior high school level; fifth, have basic knowledge, skills, and attitudes to work in the community; and, sixth, skilled to live in the community and can develop themselves following the principles of lifelong education. ${ }^{10}$

Primary school students have distinctive characteristics. Below the authors describe: the first characteristic is physical and motor development. Primary school students are individuals who experience the most physical and psychological changes. The physical development of an individual must affect his motor movements. The following are the physical characteristics of primary school students: (1) ages 7 to 9 years namely, and girls are shorter and lighter than boys; (2) ages 9 to 10 years that is, girls and boys have the same height and weight; and (3) 11 years old, in example girls have a higher and heavier posture than boys. As for motor development, children begin to develop necessary motor skills, namely balancing the body, running, jumping, and throwing. 11

The second characteristic is cognitive development. Primary school-age students experience rapid cognitive growth. Children begin to learn to form a concept, begin to

${ }^{7}$ AD, Yahya, and Siti Kristika. "Pengalaman Guru Bimbingan dan Konseling dalam Menangani Anak Berkebutuhan Khusus"

$8 \mathrm{AD}$.

${ }^{9}$ Arina Fithriyana, Dwi Yuwono Puji Sugiharto, Sugiyo. "Bimbingan Kelompok Dengan Teknik Permainan Simulasi Untuk Meningkatkan Kemampuan Komunikasi Antar Pribadi Siswa", Jurnal Bimbingan Konseling 3, no. 2 (2014): 137-142.

${ }^{10} \mathrm{AD}$, Yahya, and Siti Kristika. "Pengalaman Guru Bimbingan dan Konseling dalam Menangani Anak Berkebutuhan Khusus"

${ }^{11} \mathrm{AD}$. 


\section{Amalia Rizki Pautina, Wiwik Pratiwi, Sri Yunita Taligansing}

see relationships, solve problems in situations involving concrete objects and conditions that are familiar to them, children also have started to shift from egocentric thinking to objective thinking $^{12}$. Even, the child can understand the existence of a move to something concrete and has understood the problem of cause and effect, the child is also able to interpret a good or bad action from the consequences that result. ${ }^{13}$

The third characteristic is psychosocial development. The psychosocial development of elementary school-age students (6 to 12 years) is at the industrial versus inferiority stage. At this stage, the child realizes that he has the ability and uniqueness that makes him different from others; dependence on the family begins to decrease because the child prefers to gather with his friends. Children also start trying to do tasks and work ${ }^{14}$. Even, children begin to be responsible, children also begin to seek attention and appreciation for their work, because they like to get along, they begin to feel less confident if they are not able to do the tasks as their friends do ${ }^{15}$.

\section{Inclusive Education}

The term inclusion can be related to equality, justice, and individual rights in the distribution of resources such as politics, education, social, and economical, each of these aspects do not stand alone but are interrelated to one another. ${ }^{16}$ Regulation of the Minister of National Education Number 70 Year 2009 concerning Inclusive Education for students who have disabilities and have potential intelligence and/or unique talents, article 1 states that inclusive education is a system of providing education that provides opportunities for all students who have disabilities and have potential intelligence and or unique talents to participate in teaching or learning in the educational environment together with students in general. ${ }^{17}$

Inclusive education is an educational service for students who have special educational needs in regular schools (elementary, junior high, high school, and vocational), which are classified as extraordinary both in terms of disabilities, slow

${ }^{17}$ President of the Republic of Indonesia, "Regulation of the Minister of National Education Republic of Indonesia Law No. 70 of 2009 Concerning Inclusive Education of the Republic of
} Indonesia," 2009. 
responding to learning and experiencing other learning difficulties ${ }^{18}$. Besides, according to Mohammad Takdir, Inclusive Education is a form of educational reform that emphasizes anti-discrimination attitudes, the struggle for equal rights and opportunities, justice, and expansion of access to education for all, improving the quality of education, strategic efforts in completing 9-year compulsory education, and efforts to change people's attitudes towards children with special needs. ${ }^{19}$

Based on several opinions about the understanding of inclusive education before, it can be concluded that inclusive education is one form of educational service that does not distinguish between regular students and those with special needs both physical, intellectual, social, emotional, linguistic, and so on, including also participants students who are in remote or backward areas, indigenous peoples who are isolated, and/or experience natural disasters, social disasters, and lack of financial capacity to get education in regular schools such as SD / MI, SLTP / MTs, SMA / MA / SMK.

Also, the category of children with special needs are divided into the following: (1) the hearing impaired (deaf, deafened, with hearing loss); (2) visually impaired (blind, blinded, with low vision); (3) intellectual disabilities (mental retardation, mental retardation); (4) speech disorders; (5) disorders of the musculoskeletal system; (6) a complex structure disorders (mentally retarded blind or deaf, deaf-blind, and others.); and (7) the emotional-volitional disorders and children with autism ${ }^{20}$.

Referring to Article 32 of Law Number 20 the Year 2003 Concerning the National Education System, the author categorizes children with special needs in primary schools implementing inclusive education, as follows: first, children with permanent special needs consisting of blind children, deaf, speech impaired, mentally disabled, physically disabled, barreled, autistic, and children with unique talents and intelligence. Second, children with temporary special needs consisting of children in remote and backward areas; children in indigenous communities who are separated from other communities; children affected by natural disasters and unable to attend and complete education due to natural disasters; children affected by social disasters, is

\footnotetext{
${ }^{18}$ AD, Yahya, and Siti Kristika. "Pengalaman Guru Bimbingan dan Konseling dalam Menangani Anak Berkebutuhan Khusus"

19 AD.

${ }^{20}$ Roza A. Valeeva and Ewa M. Kulesza, "Education for Persons with Special Needs: Polish and Russian Experience," International Journal of Environmental and Science Education 11, no. 7 (2016): 1619-29, https://doi.org/10.12973/ijese.2016.367a.
} 


\section{Amalia Rizki Pautina, Wiwik Pratiwi, Sri Yunita Taligansing}

children who cannot participate in and complete education due to specified social disasters; and children from economically disadvantaged communities.

Reference in the implementation of inclusive education, consists of several principles, as follows: first, the principle of equity and quality improvement. Inclusive education is one of the strategies to equalize opportunities in obtaining an education because inclusive education institutions can accommodate all children who have not been reached by other education services. Inclusive education is also a quality improvement strategy because the inclusive learning model uses varied learning methods and can cover all children but still respect differences. Second, the principle of individual needs. Education must be endeavored to suit the child's condition because every child has different abilities and needs. Third, meaningfulness principle. Inclusive education creates and maintains friendly class communities, accepts diversity, and values diversity. Fourth, the principle of sustainability. Inclusive education is carried out regularly at all grades of education. Fifth, the principle of involvement. Inclusive education involves all related to education components. ${ }^{21}$

Usman Abu Bakar formulated the two principles of inclusive education as follows: first, the principle of equal rights in education. Inclusive education accommodates all children to get quality education, respect diversity, and recognize individual differences. Second, the principle of improving school quality. Strive to always improve the quality and quality of schools, starting in the provision of facilities and infrastructure, the ability of teachers, and changing school views about the needs of children, collaborating with related institutions as partners to improve the quality of schools, and creating a school that is friendly to children so that children feel safe and comfortable to learn and interact with peers. ${ }^{22}$

Based on the formulation of the basic principles of inclusive education according to previous experts, authors conclude that the basic principles of implementing inclusive education in primary schools must accommodate the needs of each student by providing facilities and infrastructure, formulating a flexible curriculum and involving stakeholders so that education services run optimally.

${ }^{21}$ AD, Yahya, and Siti Kristika. "Pengalaman Guru Bimbingan dan Konseling dalam Menangani Anak Berkebutuhan Khusus"

${ }^{22} \mathrm{AD}$. 
Meanwhile, the implementation of inclusive education in Indonesia is regulated in the Act, while the objectives of inclusive education, as stated in Law Number 70 of 2009 Article 2 are: first, provide the broadest opportunity for all students who have physical, emotional, mental, and social disabilities or have the potential for intelligence and unique talents to obtain quality education following their needs and abilities; second, realizing the implementation of education that respects diversity and does not discriminate against all students as referred to in letter a Indonesia.

Furthermore, the objectives of implementing inclusive education in Indonesia, according to the Ministry of National Education, are as follows: first, providing the broadest possible opportunities for all children (including children with special needs) to get an appropriate education under their needs; second, accelerate the compulsory primary education learning program; third, improve the quality of primary and secondary education by suppressing the number of children falling behind classes and dropping out of school; fourth, creating an educational environment that respects diversity, is non-discriminatory, and is friendly to learning; fifth, fulfill the mandate of the 1945 Constitution, specifically Article 32 paragraph 1, Law Number 20 of 2003 Article 5 paragraph 1, Law Number 23 of 2002 concerning child protection Article 51. 23

Based on the objectives of inclusive education that have been described previously, in the implementation of inclusive education, schools are required to make adjustments starting from the curriculum, infrastructure, and learning systems so that it suits the needs of students. This necessity is because inclusive education seeks to provide equal opportunities for each student to obtain a decent and quality education to develop their potential.

\section{Guidance and Counseling in Schools}

The word "Bimbingan Konseling" comes from English, namely guidance and counseling. Rochman Natawidjaja defines guidance as a process of assisting individuals carried out on an ongoing basis so that individuals can understand themselves, direct themselves, and can act appropriately under the demands and circumstances of the

\footnotetext{
23 AD.
} 


\section{Amalia Rizki Pautina, Wiwik Pratiwi, Sri Yunita Taligansing}

family and community. Thus he can feel the happiness of his life and can make a meaningful contribution ${ }^{24}$.

Furthermore, Prayitno and Amti interpret guidance as the process of providing assistance carried out by experts on the psychology of a person or several individuals, both children, adolescents, and adults so that the people being guided can develop their own and independent abilities, by utilizing individual strengths and means existing and can be developed based on applicable norms. ${ }^{25}$

Walgito argued that counseling is the assistance given to individuals to solve life problems through interviews and following the circumstances faced by individuals to achieve prosperity in life. ${ }^{26}$ Furthermore, Nurihsan defines counseling as an effort to help individuals through a process of personal interaction between counselor and counselee so that the counselee can understand themselves and their environment, able to make decisions and set goals based on the values they believe so that the counselee feels happy and useful behavior. ${ }^{27}$

Based on the exposure of previous experts on the definition of guidance and counseling, the authors conclude that guidance and counseling is a process of assisting individuals or groups carried out by counselors so that the people being guided can solve their problems, develop their abilities and become independent to achieve happiness in his life. Meawhile, the implementation of guidance and counseling services has a purpose. The general purpose of implementing guidance and counseling services is to make counselees independent. If linked to inclusive education in primary schools, the purpose of guidance and counseling services is to help children become independent, able to accept themselves and to understand themselves.

There are nine types of services in guidance and counseling, as for the types of services used in the guidance and counseling program in primary schools implementing inclusive education, as follows: the first type is orientation service. Orientation services are services provided to counselees in this case students to know something new. The goal of this service is to help students have an understanding so that they can adapt to new environments, conditions, or situations. The second type is information services.

\footnotetext{
${ }^{24} \mathrm{AD}$.

${ }^{25} \mathrm{AD}$.

26 AD.

${ }^{27} \mathrm{AD}$.
} 
Information services are services provided to students so that they have an understanding and knowledge of themselves and their environment so they can make the right decisions for their lives. The provision of information can be through direct or indirect communication. Information is also adjusted to the child's ability to communicate, especially when communicating with children who are blind or speech impaired. The goal of this service is to help students find information that can make them able to organize and plan their lives.

The third type is placement and distribution services. Placement and distribution services are services provided to the counselee in order to be able to occupy a place or environment by the conditions of students. This service aims to help students in occupying a place or environment that suits them so that students can develop their potential optimally. Also, this service aims to help students get the right environment related to their abilities and interests. The fourth type is content mastery services. Content mastery service is a tutoring service provided to students to be able to master a competency. This service aims to help students to be able to master specific competencies through learning activities, besides, this service is also to form an understanding and mastery of certain skills so that students are able to overcome the problems they face.

The fifth type is individual counseling services. Individual counseling services are services provided to students so that the problems encountered are overcome. This service aims to help students master the problems they face through counseling interviews using counseling techniques and theories. The sixth type is group counseling services. Group counseling services are services provided to several students to help overcome personal problems they face through group activities by utilizing group dynamics. This service aims to resolve the issues faced by group members and develop the ability to socialize and communicate with others. The seventh type is group guidance services. Group guidance services are services provided to several people in a group format so that group dynamics are created and useful for self-development and problem solving for group members. This service aims to help students develop their social skills, increase their courage of opinion and communication skills, and help students to solve common problems they face. 
The eighth type is mediation services. Mediation services are services provided to two or more parties who are experiencing a disharmony or are in dispute. This service aims to create new and favorable conditions of relations between the parties in conflict. Ninth type is consultation services. Consultation services are services provided by counselors to students to obtain information, understanding, and ways that can be done to help resolve third-party problems. This service aims to provide students with knowledge, information, insight, and methods so that students can overcome issues that are being faced by third parties, where third parties have a reasonably close relationship with students.

Besides the nine types of services described earlier, in the counseling guidance program in inclusive education in primary schools, there are also support activities that must be carried out by counselors, in this case, teachers in primary schools. The supporting activities are as follows: first, instrumentation application, this activity is data collection and student information; second, the collection of data, data collected from various things about the characteristics of students, conditions, and things that support it; third, a case conference is a forum that brings several parties together to discuss students' problems; fourth, home visits, collecting data, and information by visiting students' homes to solve the problem; fifth, transferring the case, moving the case to another party to get more appropriate handling.

The guidance and counseling program is a series of guidance and counseling that is arranged systematically, planned, organized, and coordinated in a particular time ${ }^{28}$. The guidance and counseling program is also interpreted as an overall plan of guidance and counseling activities that will be carried out in specific periods, such as an annual, semester, monthly, weekly and daily programs ${ }^{29}$. The definition of a guidance and counseling program that refers to the opinion of previous experts is a series of counseling guidance activities that are arranged systematically, planned, organized, and coordinated in the annual, semester, monthly, weekly, and daily periods.

In the guidance and counseling (GC) program in inclusive education in primary schools, the preparation of the program must be based on the needs and conditions of children with special needs, regular children, and children with other requirements in

28 AD.

${ }^{29}$ Dewa Ketut Sukardi, Pengantar Pelaksanaan Program Bimbingan dan Konseling di Sekolah (Jakarta: Rineka Cipta, 2008), p. 7. 
inclusive schools. In the implementation of the GC programs in schools, four approaches can be used, including: first, a crisis approach, which is taken to overcome problems, second, a remedial approach that is carried out by fixing things that cause problems, third, a preventive approach taken to prevent problems, and, fourth, developmental approaches taken to optimize the development of students. ${ }^{30}$

Teachers in primary schools implementing inclusive education must create guidance and counseling programs based on the objectives to be achieved within a specified period. Teachers in schools providing inclusive education must make the following types of programs: first, the annual program, the annual program is based on the evaluation of the previous year's program, and the current program will be a reference in preparing the guidance and counseling program for the coming year. In the implementation of inclusive schools, programs are integrated into one another. The annual program includes semester programs. Second, monthly programs, monthly programs contain weekly and daily programs. The monthly program includes all activities to be carried out for one month, and the counselor must modify according to the needs of students both regular and those with special needs. Third, the daily program is a program that will be implemented on certain days for one week. The daily program is a derivative of the weekly schedule. The types of programs in regular schools and schools providing inclusive education are almost the same, except that in inclusive education programs are arranged according to the situation of students combining healthy children and children with special needs in one class.

\section{Guidance and Counseling Programs For Inclusive Education In Primary Schools}

Guidance and counseling programs in inclusive schools are structured to help students achieve personal, social, learning, and career independence. Children with Special Needs are children with disabilities in the development of life due to disruption (mental, intellectual, emotional, social, physical) in the social-social, career, and academic fields, so they need special services and are different from children in general.

${ }^{31}$ Kustawan said that guidance and counseling for children with special needs are to

30 Widada, "Program Bimbingan Dan Konseling Di Sekolah Dasar," Jurnal Pemikiran Dan Pengembangan Sekolah Dasar (JP2SD) 1, no. 1 (2013): 65, https://doi.org/10.22219/jp2sd.v1i1.1531.

31 Muya Barida and Dian Ari Widyastuti, “Acceptance and Commitment Therapy (ACT) to Improve Educators Self-Acceptance of Children with Special Needs" 06, no. 2 (2019): 117-24. 


\section{Amalia Rizki Pautina, Wiwik Pratiwi, Sri Yunita Taligansing}

help them get to know themselves, find their specific needs according to obstacles, and their disorders. ${ }^{32}$

Guidance and counseling service programs in primary schools providing inclusive education tailored to the special needs of children individually in the context of classifying together between children with special needs and normal children. The guidance and counseling program in inclusive schools is directed at developing personality and life skills so that students are able to participate in the community and not become a burden on the family or community.

A successful program is a program that runs well, is sustainable and under the stated goals. To maximize the achievement of the program that has been prepared, there are stages in the implementation of the program. Gysber and Henderson in Sugiyo stated that there were four stages in the implementation of the guidance and counseling program, which included planning, designing, implementing, and evaluating. ${ }^{33}$

First stage is planning. Guidance and counseling program planning aims to provide maximum services to children with special needs and normal children without discrimination. There are several activities in the planning stage, as follows: (1) examining the needs and problems of students following the task of development; (2) classifying the objectives to be achieved by taking into account both general and special purposes; (3) making a limit on the type of program made, the intended limit relates to the time the program implemented; (4) examining the types of programs that already exist to prevent duplication of programs to be prepared, and streamline the implementation time of the program; (5) seek support and cooperation from school staff, parents, and the community; (6) determine program priorities. ${ }^{34}$

The second stage is designing. The designing of guidance and counseling programs in primary schools providing inclusive education must refer to the needs of each student, both regular and those with special needs. Gysber and Henderson suggest that several activities must be carried out at this stage, as follows: (1) formulating program objectives compiled operationally in the form of measurable service activities; (2) choosing strategies and techniques for implementing programs that are tailored to the needs of students, the conditions and situation of the school; (3) describe in detail

\footnotetext{
${ }^{32}$ Widada, "Program Bimbingan Dan Konseling Di Sekolah Dasar."

${ }^{33}$ Widada

${ }^{34}$ Widada
} 
the components of the program; (4) analyzing the ability of school staff; and (5) carry out capacity building for school staff. ${ }^{35}$

The third stage is implementation. The implementation of guidance and counseling programs in elementary schools providing inclusive education facilitates students to be able to achieve developmental tasks that are appropriate to their development phase. Therefore, in implementing the guidance and counseling program, there are several activities as follows: (1) identify resources that include normal and special learners, school principals, class teachers, subject teachers, counselors, parents/guardians, and so forth. Infrastructure facilities and implementation times also need to be identified to support the success of the program; (2) create instruments that measure program success; (3) implement programs and adjust programs arranged by programs from other schools; (4) make revisions or improvements to the program based on the results of the distribution of instruments. ${ }^{36}$

The implementation of the counseling guidance program must be based on a particular time. To make the implementation time-efficient, the counselor must make a schedule. Following in Figure 1 is the schedule for the implementation of guidance and counseling programs in inclusive education in primary schools:

SCHEDULE

IMPLEMENTATION OF GUIDANCE AND COUNSELING PROGRAMS

\begin{tabular}{|c|c|c|c|c|c|c|c|c|c|c|c|c|c|c|c|c|c|c|c|c|}
\hline \multirow{3}{*}{ No } & \multirow{2}{*}{ ACTIVITIES } & \multicolumn{6}{|c|}{ CLASS } & \multicolumn{12}{|c|}{ TIME } & \multirow{2}{*}{ EXPL } \\
\hline & & 1 & 2 & 3 & 4 & 5 & 6 & JAN & FEB & MAR & APR & MAY & JUN & JUL & AUG & SEP & OCT & NOV & DES & \\
\hline & Preparation & & & & & & & & & & & & & & & & & & & \\
\hline 1 & Need Assessment & & & & & & & & & & & & & & & & & & & \\
\hline 2 & $\begin{array}{l}\text { Compiling the Guidance and } \\
\text { Counseling Program }\end{array}$ & & & & & & & & & & & & & & & & & & & \\
\hline 3 & $\begin{array}{l}\text { Coordination the Program with } \\
\text { Principals and Parents }\end{array}$ & & & & & & & & & & & & & & & & & & & \\
\hline 4 & $\begin{array}{l}\text { Procurement of Facilities and } \\
\text { Infrastructure }\end{array}$ & & & & & & & & & & & & & & & & & & & \\
\hline & IMPLEMENTATION & & & & & & & & & & & & & & & & & & & \\
\hline & Basic Services & & & & & & & & & & & & & & & & & & & \\
\hline 1 & Orientation Services & & & & & & & & & & & & & & & & & & & \\
\hline 2 & Information Services & & & & & & & & & & & & & & & & & & & \\
\hline 3 & $\begin{array}{l}\begin{array}{l}\text { Placement and Distribution } \\
\text { Services }\end{array} \\
\end{array}$ & & & & & & & & & & & & & & & & & & & \\
\hline 4 & Content Mastery Services & & & & & & & & & & & & & & & & & & & \\
\hline 5 & Consultation Services & & & & & & & & & & & & & & & & & & & \\
\hline 6 & Mediation Services & & & & & & & & & & & & & & & & & & & \\
\hline 7 & Individual Counseling Service & & & & & & & & & & & & & & & & & & & \\
\hline 8 & Group Counseling Service & & & & & & & & & & & & & & & & & & & \\
\hline 9 & Group Guidance Services & & & & & & & & & & & & & & & & & & & \\
\hline & Supporting Activities & & & & & & & & & & & & & & & & & & & \\
\hline 1 & Instrumenting Application & & & & & & & & & & & & & & & & & & & \\
\hline 2 & Polling the Data & & & & & & & & & & & & & & & & & & & \\
\hline 3 & Case Conference & & & & & & & & & & & & & & & & & & & \\
\hline 4 & Home Visiting & & & & & & & & & & & & & & & & & & & \\
\hline 5 & Transfering the Case & & & & & & & & & & & & & & & & & & & ctiv \\
\hline & EVALUATION & & & & & & & & & & & & & & & & & & & \\
\hline
\end{tabular}

Figure 1.

Schedule Implementation of Guidance Counseling Programs

\footnotetext{
${ }^{35}$ Widada

${ }^{36}$ Widada
} 


\section{Amalia Rizki Pautina, Wiwik Pratiwi, Sri Yunita Taligansing}

The fourth stage is evaluation. Evaluation of guidance and counseling programs in primary schools providing inclusive education tends to be more detailed and complicated because it is not only prioritized for normal children but also children with special needs. There are three types of assessment carried out in the process of assessing the guidance and counseling program, as follows: the first type is personal assessment. Personnel assessment is a procedure for determining the effectiveness of the work of a counselor or homeroom teacher or accompanying teacher in implementing guidance and counseling programs in primary schools providing inclusive education. The second type is process assessment. The assessment process is done through an analysis of the effectiveness of the guidance and counseling program. The scope of the assessment process includes all types of essential services and support services provided by the counselor, assistant teacher or homeroom teacher.

Meanwhile, the third type is evaluation of the results. Evaluation of the results aims to find out developments that occur in students after the guidance and counseling program is given. Evaluation of the results consists of: (1) immediate assessment (laiseg), i.e. initial assessment which is carried out after being provided services; (2) short-term assessment (laijapen), which is a follow-up assessment conducted a few days after the implementation of the service; and (3) long-term assessment (laijapang), which is a comprehensive assessment carried out at intervals of a particular time unit, for example semester. ${ }^{37}$

\section{CONCLUSION}

The results of the discussion showed that the implementation of the guidance and counseling program in primary schools implementing inclusive education must be adjusted to the characteristics of students, the programs arranged were not discriminatory because they were intended for normal students or those with special needs. The category of children with special needs is divided into two, namely children with permanent special needs and children with temporary special needs.

The guidance and counseling program that was created aims to help students in elementary schools implementing inclusive education, become independent, know themselves, and be able to accept themselves. A successful program is a program that

\footnotetext{
${ }^{37}$ Widada
} 
runs well, sustainable, and following the stated goals. To maximize the achievement of the program that has been compiled, the following are the stages of the implementation of the counseling guidance program: planning, designing, implementing, and evaluating.

Therefore, to optimize the achievement of the implementation guidance and counseling programs that have been designed, the author expects that the teachers in primary school can apply for the programs and be adapted to the needs of students in their respective schools, bearing in mind that not all primary schools in Indonesia have counselor or guidance teachers.

\section{REFERENCES}

AD, Yahya, and Siti Kristika. "Pengalaman Guru Bimbingan dan Konseling dalam Menangani Anak Berkebutuhan Khusus", Konseli: Jurnal Bimbingan dan Konseling 02, no. 2 (2015): 43-49.

Badiah, Lutfi Isni. "Urgensi Bimbingan Dan Konseling Bagi Anak Berkebutuhan Khusus (ABK) Di Sekolah Inklusi," Prosiding Seminar Nasional Peran Bimbingan dan Konseling dalam Penguatan Pendidikan Karakter Universitas Ahmad Dahlan, 2017, 123-31.

Barida, Muya, and Dian Ari Widyastuti. "Acceptance and Commitment Therapy (ACT) to Improve Educators Self-Acceptance of Children with Special Needs", Konseli: Jurnal Bimbingan dan Konseling 06, no. 2 (2019): 117-24.

Fithriyana, Arina, Dwi Yuwono Puji Sugiharto, Sugiyo. "Bimbingan Kelompok Dengan Teknik Permainan Simulasi Untuk Meningkatkan Kemampuan Komunikasi Antar Pribadi Siswa", Jurnal Bimbingan Konseling 3, no. 2 (2014): 137-142.

Hanjarwati, Astri, and Siti Aminah. "Evaluasi Implementasi Kebijakan Pemerintah Kota Yogyakarta Mengenai Pendidikan Inklusi." Inklusi 1, no. 2 (2014): 221. https://doi.org/10.14421/ijds.010206.

Minister of National Education Republic of Indonesia, "Inclusive Education of the Republic of Indonesia," Regulation of the Minister of National Education Republic of Indonesia Law No. 70 of 2009, 2009.

President of Republic of Indonesia, "the National Education System", Law of the Republic of Indonesia Number 20 of 2003, Pemerintah Republik Indonesia, 2003.

Purba, Tika Anggreni. "70 Persen Anak Berkebutuhan Khusus Tak Dapat Pendidikan Layak”, https://lifestyle.bisnis.com/read/20190326/236/904431/70-persen-anakberkebutuhan-khusus-tak-dapat-pendidikan-layak, pada tanggal 29 Agustus 2019 pukul 14.20. 


\section{Amalia Rizki Pautina, Wiwik Pratiwi, Sri Yunita Taligansing}

Valeeva, Roza A., and Ewa M. Kulesza. "Education for Persons with Special Needs: Polish and Russian Experience." International Journal of Environmental and Science Education 11, no. 7 (2016): 1619-29. https://doi.org/10.12973/ijese.2016.367a.

Widada, "Program Bimbingan Dan Konseling Di Sekolah Dasar." Jurnal Pemikiran Dan Pengembangan Sekolah Dasar (JP2SD) 1, no. 1 (2013): 65. https://doi.org/10.22219/jp2sd.v1i1.1531.

Yulianto, M. Joni. "Konsepsi Disabilitas Dan Pendidikan Inklusif." Inklusi 1, no. 1 (2014): 19. https://doi.org/10.14421/ijds.010102. 
Guidance and Counseling Programs for Inclusive... 